\title{
Some Metabolic Responses as Affected by Dietary Sugar Beet Pulp and Enzymes Additions in Growing Rabbits
}

\author{
Abd El-Ghani, AKh Abdel-Moty, BE Soliman and Aya SA Abd El-Latif* \\ Department of Animal Production, Faculty of Agriculture, Minia University, Minia, Egypt \\ *Corresponding Author: SA Abd EL-Latif, Department of Animal Production, Faculty of Agriculture, Minia University, Minia, Egypt.
}

Received: May 27, 2019; Published: July 02, 2019

DOI: 10.31080/ASNH.2019.03.0357

\begin{abstract}
A total number (36) of male New Zealand White (NZW) rabbits of 8 weeks age was assigned at random to six groups (6 males) per each to evaluate some metabolic responses as affected by dietary sugar beet pulp and enzymes. The whole period of the experiment was from 8 to 16 weeks of age. Three levels of sugar beet pulp (SBP) were used at levels of 0, 50 and $100 \%$ and two levels of enzymes preparation Kemzyme (Enz) at 0 and $500 \mathrm{~g} /$ ton of the diet were used in a $3 \times 2$ factorial arrangement. At the end of experimental, blood samples were collected in non- heparinized tube and centrifuged for 5 minutes at 10000 R.P.M to separate, serum. The separated serum used for studding some blood metabolites parameters. The data revealed that, rabbits fed dietary contain 100\% SBP and incorporated with enzyme recorded the greatest $(\mathrm{p}<0.05)$ value of glucose and triglycerides followed by others fed dietary contain $50 \%$ SBP and incorporated with enzyme compared with all dietary (SBP $\times$ enzyme). Using either SBP or adding enzyme to rabbit diets did not significantly affect on the values of total protein, albumin, globulin, and cholesterol. The best $(\mathrm{P}<0.05)$ enhancement in the values of AST and AST/ALT ratio were recorded for rabbit fed dietary enzyme compared with the control diet. While, insignificantly improvement in ALT, U/L and AST/ALT ratio was shown for rabbits fed control diet either with or without enzyme addition compared with all dietary interaction treatments. It could be concluded that using SBP up to $100 \%$ in rabbit diets with exogenous enzymes improved glucose and triglycerides with no effect on total protein, albumin, globulin, and cholesterol. Also, adding enzymes to rabbit diets may enhance liver enzymes.
\end{abstract}

Keywords: Metabolic Responses; Rabbits; SBP

\section{Introduction}

Minimizing the feed cost could be achieved through the use of untraditional feed ingredients or improving utilization of common feeds by using some chemical or natural feed additives. Some studies designed to utilize some agricultural and agro-industrial by products in animal feeding, especially as alternatives to clover hay, which commonly represents about $30-40 \%$ of the complete pelleted diets. The available amount of clover hay is usually insufficient for animal feeding leading to increasingly prices for diets. Rabbit diets necessarily contain high levels of fibrous feeds yet are fundamental to the digestive process of the species [1].

In the Western Europe, approximately half of the pressed pulp might be used directly on the farm, either fed fresh or ensiled. Pressed pulp can be dried alone or combined with molasses, but pelleting is helped by the addition of molasses. Nutritionally, molassed beet pulp pellets have the roughage properties of chopped hay and the high energy characteristics of corn. This feature makes molassed beet pulp pellets a value able feed for cattle feeders, dairies and lamb feeding operations [2]. Dried beet pulp, a carbohy- drate rich by-product of the sugar industry, has been used as a partial source of energy in the rations of sheep [3], and rabbits diets [4,5], and EL-Badawi., et al. [6] and Salah Eldin., et al [7].

Dietary enzyme supplementation is used widely in mono-gastric diets in attempts to improve nutrient utilization and health. It is used also to improve product quality and to reduce pollution as well as to increase the choice and content of ingredients which are acceptable for inclusion in diets [8]. Five principles and reasons for dietary enzyme usage; hydrolysis of phytic acid for the release phosphorus, break down cell walls eliminating the encapsulating effect improving energy and amino acid availability, improving hindgut fermentation by solubilizing cell walls, hydrolyze carbohydrate-protein linkages improving amino acid availability and eradication of anti-nutritive properties by enzymatic hydrolysis to prebiotic type components improving gut development and health in young birds or poultry [9]. Generally, using sugar beet bulb as feed stuff for animals, indicated that there are positive affects of using suger beet plub on the productive performance of rabbit $[3,7,10]$ and, while some studies, indicated that there no significant effect 
of using sugar beet blub on the productive performance of rabbit Cobos., et al. [11]; Zaza [5]; and of sheep [12,13]. Moreover, there are variation of the literature at the effect of enzyme supplementation. Some investigators found that supplementation of enzyme in the ration recorded a positive effect on the performance or rabbits $[14,15]$, While other experiments showed that there are no significant effect of enzyme supplementation on the ration of rabbit Eiben., et al [16]; Fasiullah., et al [17].

Thus, the aim of this study was to evaluate the effect of using difference levels of Sugar beet pulp (SBP) with or without enzymes preparation on some blood metabolizes of New Zealand White rabbits.

\section{Materials and Methods}

The present study was carried out at the farm of Animal and Poultry Production, Faculty of Agriculture, Minia University, during the period from March (2016) to Jun (2016). The aim of this study was to evaluate the effect of using grade levels of SBP (0, 50 and $100 \%$ ) and incorporated with or without enzyme mixture (cellulase, $\beta$-glucanase, $\alpha$-amylase, protease and lipase) of the diet on some metabolic responses of New Zealand White rabbits.

\section{Experimental design}

A total number of 36 male New Zealand White (NZW) rabbits of 8 weeks age was individually housed and assigned at random to six groups (6 males) per each. Each individual rabbit was allocated in a cage with slatted floor of iron $(45 \times 45 \times 38 \mathrm{~cm})$ for length, width and height, respectively. Water and feed were given to the rabbits ad-libitum during the experimental period from 8 to 16 weeks of age. Three levels of sugar beet pulp were used at levels of 0 (control), 50 and $100 \%$ and two levels of enzymes preparation Kemzyme (Enz) at 0 and $500 \mathrm{~g} /$ ton of the diet were used in a $3 \times 2$ factorial arrangement. Each 1 gram of enzymes contains 440 $\mu / g$ xylanase-EC3218, $150 \mu / g ~ \beta$-glucanase e-EC3218, 480 $\mu / g$ cellulose-EC321151, $450 \mu / g \alpha$-amylase-EC3421, $750 \mu / g$ serine protease-EC3421, $450 \mu / g$ subtilisine serine protease-EC3 and 422,200 $\mu / \mathrm{g}$-EC 31326 Phytase. The commercial enzymes carrier material is calcium carbonate up to $1 \mathrm{~kg}$. All experimental diets were formulated to contain adequate levels of nutrients for growing New Zealand White rabbits as recommended by NRC [18] All experimental design were prepared to be isonitrogenous and iso-caloric. The composition and analysis of dietary treatments are shown in Table 1 . The chemical composition sugar beet pub and berseem hay are show in Table 2 and the experimental six treatments are show in Table 3.

\begin{tabular}{|c|c|c|c|c|c|c|}
\hline \multirow{4}{*}{ Ingredients \% } & \multicolumn{6}{|c|}{ Experimental diet } \\
\hline & T1 & T2 & T3 & T4 & T5 & T6 \\
\hline & \multicolumn{3}{|c|}{$\begin{array}{c}\begin{array}{c}\text { Sugar beet pulp } \\
\text { levels }\end{array} \\
\text { Without enzymes }\end{array}$} & \multicolumn{3}{|c|}{$\begin{array}{c}\text { Sugar beet pulp levels } \\
\text { With enzymes }\end{array}$} \\
\hline & $\mathbf{0}$ & 50 & 100 & $\mathbf{0}$ & 50 & 100 \\
\hline $\begin{array}{l}\text { Ground yellow } \\
\text { corn }\end{array}$ & 36.95 & 33.45 & 29.30 & 36.95 & 33.45 & 29.30 \\
\hline Soya bean meal & 16.50 & 20.80 & 24.20 & 16.50 & 20.80 & 24.20 \\
\hline Berseem hay & 25.00 & 12.50 & 0.00 & 25.00 & 12.50 & 0.00 \\
\hline Sugar beet pulp & 0.00 & 12.50 & 25.00 & 0.00 & 12.50 & 25.00 \\
\hline Wheat bran & 19.75 & 18.95 & 19.70 & 19.75 & 18.95 & 19.70 \\
\hline Lime stone & 1.00 & 1.00 & 1.00 & 1.00 & 1.00 & 1.00 \\
\hline Salt & 0.50 & 0.50 & 0.50 & 0.50 & 0.50 & 0.50 \\
\hline Premix* & 0.30 & 0.30 & 0.30 & 0.30 & 0.30 & 0.30 \\
\hline Total & 100 & 100 & 100 & 100 & 100 & 100 \\
\hline \multicolumn{7}{|c|}{ Calculated analyses $\%$} \\
\hline ME (kcal/kg) & $\begin{array}{c}2336 . \\
76\end{array}$ & $\begin{array}{c}2431 . \\
66\end{array}$ & $\begin{array}{c}2500 . \\
02\end{array}$ & $\begin{array}{c}2336 . \\
76\end{array}$ & $\begin{array}{c}2431 . \\
66\end{array}$ & $\begin{array}{c}2500 . \\
02\end{array}$ \\
\hline Crude protein, & 18.04 & 18.19 & 18.05 & 18.04 & 18.19 & 18.05 \\
\hline Crude fiber, & 9.46 & 9.50 & 9.73 & 9.46 & 9.50 & 9.73 \\
\hline Calcium, & 0.87 & 0.92 & 0.99 & 0.87 & 0.92 & 0.99 \\
\hline $\begin{array}{l}\text { Available phos- } \\
\text { phorus }\end{array}$ & 0.47 & 0.49 & 0.51 & 0.47 & 0.49 & 0.51 \\
\hline Methionine, & 0.79 & 0.81 & 0.81 & 0.79 & 0.81 & 0.81 \\
\hline Lysine, & 0.37 & 0.33 & 0.29 & 0.37 & 0.33 & 0.29 \\
\hline
\end{tabular}

Table 1: The composition and calculated chemical analysis of dietary treatments.

*Each2.5 kg of vitamins and minerals mixture contains: 12000.000 IU vitamin A acetate; 2000.000 IU vitamin D3; 10.000 mg vitamin E acetate; 2000 mg vitamin K3; 100 mg vitamin B1; 4000 mg vitamin B2; 1500 mg vitamin B6; 10 mg vitamin B12; $10.000 \mathrm{mg}$ pantothenic acid; $20.000 \mathrm{mg}$ Nicotinic acid; $1000 \mathrm{mg}$ Folic acid; $50 \mathrm{mg}$ Biotin; $500.000 \mathrm{mg}$ chorine; $10.000 \mathrm{mg}$ Copper; 1000 mg Iodine; 300.00 mg Iron; 55.000 mg Manganese; 55.000 mg Zinc, and $100 \mathrm{mg}$ Selenium

\begin{tabular}{|l|c|c|c|c|c|c|c|}
\hline \multicolumn{1}{|c|}{ Item } & $\begin{array}{c}\text { DM } \\
\mathbf{\%}\end{array}$ & $\begin{array}{c}\text { Ash } \\
\mathbf{\%}\end{array}$ & $\begin{array}{c}\text { OM } \\
\mathbf{\%}\end{array}$ & $\begin{array}{c}\text { CP } \\
\mathbf{\%}\end{array}$ & $\begin{array}{c}\text { CF } \\
\mathbf{\%}\end{array}$ & $\begin{array}{c}\text { EE } \\
\mathbf{\%}\end{array}$ & $\begin{array}{c}\text { NFE } \\
\mathbf{\%}\end{array}$ \\
\hline $\begin{array}{l}\text { Sugar beet } \\
\text { pulp }\end{array}$ & 90.50 & 3.90 & 86.60 & 8.96 & 19.72 & 0.52 & 75.40 \\
\hline $\begin{array}{l}\text { Berseem } \\
\text { hay }\end{array}$ & 87.82 & 14.07 & 85.94 & 13.40 & 26.25 & 2.25 & 44.04 \\
\hline
\end{tabular}

Table 2: Chemical composition sugar beet pulp and berseem hay used in the experimental treatments. 


\begin{tabular}{|c|c|}
\hline $\begin{array}{c}\text { No of } \\
\text { treatments }\end{array}$ & Treatments \\
\hline $\mathrm{T} 1$ & $\begin{array}{c}\text { Control diet ( } 100 \% \text { Hay, } 0 \% \text { sugar beet pulp and } \\
\text { no enzyme ddition) }\end{array}$ \\
\hline $\mathrm{T} 2$ & $\begin{array}{c}\text { Diet contain } 50 \% \text { Hay, } 50 \% \text { sugar beet pulp and } \\
\text { no enzyme addition }\end{array}$ \\
\hline T3 & $\begin{array}{c}\text { Diet contain } 0 \% \text { Hay, } 100 \% \text { sugar beet pulp and } \\
\text { no enzyme addition }\end{array}$ \\
\hline $\mathrm{T} 4$ & $\begin{array}{c}\text { Diet contain } 100 \% \text { Hay, } 0 \% \text { sugar beet pulp and } \\
\text { enzyme addition }\end{array}$ \\
\hline T5 & $\begin{array}{c}\text { Diet contain } 50 \% \text { Hay, } 50 \% \text { sugar beet pulp and } \\
\text { enzyme addition }\end{array}$ \\
\hline T6 & $\begin{array}{c}\text { Diet contain } 0 \% \text { Hay, } 100 \% \text { sugar beet pulp and } \\
\text { enzyme addition }\end{array}$ \\
\hline
\end{tabular}

Table 3: The experimental treatments.

\section{Collection of blood samples}

At the end of experimental period ( 6 weeks of age, blood samples were collected. Samplings were taken at 7 O'clock in the morning before feeding. Three rabbits from each treated groups were chosen, blood samples were immediately collected from each rabbit in non- heparinized tube and centrifuged for 5 minutes at 10000 R.P.M to separate, serum, which stored at $\left(-20^{\circ} \mathrm{C}\right)$ for the immunological tests (hemagglutination test, determination of immunoglobulin's), and some blood metabolites parameters.

Blood analysis

Metabolites parameters

- Serum total protein concentration (TP): Serum total protein content was determined according to the method of Tietz [19] using commercial kits.

- Serum albumin concentration (Alb): Serum albumin concentration was determined according to the method of Tietz and Saunders [20] using commercial kits.

Serum globulin concentration and albumin/globulin (Alb: Glob) ratio

Serum globulin concentration and albumin/globulin (Alb: Glob) ratio were calculated using the following equations:

Globulin $(\mathrm{gm} / \mathrm{l})=$ Total proteins $(\mathrm{gm} / \mathrm{l})-$ Albumin $(\mathrm{gm} / \mathrm{l})$

Albumin/Globulin (Alb: Glob) ratio $=\frac{\text { Albumin }(\mathrm{gm} / \mathrm{l})}{\text { Globulin }(\mathrm{gm} / \mathrm{l})}$

\section{Serum of AST}

Aspartate aminotranaferase (AST, U/L) activity in serum was determined according to Young [21] using commercial kits.

\section{Serum of ALT}

Alanine aminotransferase (ALT, U/L) activity in serum was determined according to Young [21] using commercial kits.

\section{Statistical analysis}

Data were subjected to two-way analysis of variance applying SAS program [22] using general linear model GLM. The statistical model was as follow:

$Y i j k=\mu+T i+E j+T i E j+e i j k$

Yijk: Observation measured, $\mu$ : Overall mean, Ti: Sugar beet pulp (i=1,.. 3),

Ej: Effect of enzymes $(j=1,2)$, TEij: Effect of sugar beet pulp $x$ enzyme interaction ( $i j=1, \ldots 6)$, eijk: Experimental error. Significant differences among treatment means were separated using Duncan Multiple Range procedure Duncan [23].

\section{Results and Discussion}

The effects of sugar beet pulp levels (diets), enzyme (E) addition, and the interaction between SBP diets and enzyme (E) addition on some metabolites responses such as total protein, albumin, globulin, glucose, triglycerides and cholesterol of growing rabbits at the end of the experiment are presented in Table 4.

\section{Effect of sugar beet pulp levels (diets)}

Average values of some metabolites responses such as total protein, albumin, globulin, glucose, triglycerides and cholesterol of growing rabbits as affected by using different levels of SBP in their diet at the end of the experiment are presented in Table 4.

The data revealed that, using SBP at all levels in rabbit diets had no significantly effect on the values of in all previous blood metabolic responses except the values of triglycerides which recorded a significant improvement $(\mathrm{P} \geq 0.05)$ as increasing the level of SBP in rabbit diets up to $100 \%$ compared with other SBP levels. All values of total protein, albumin, globulin, glucose, and cholesterol were almost similar for dietary SBP at all levels. No significantly effect was detected in the values of triglycerides as affected of increasing SBP in rabbit diets up to 50\%. The same result obtained by Abd ELLatif., et al [24]. They revealed that using SBP as a replacement of hay in rabbit diets recorded no significant differences in total Lipids (g/dl) and glucose (mg/dl). Wille, rabbits fed dietary $100 \%$ SBP recorded the highest $(\mathrm{P}<0.05)$ values of total protein, globulin, and glucose compared with other dietary treatments.

\section{Effect of enzyme addition}

Average values of some blood metabolic responses such as such as total protein, albumin, globulin, glucose, triglycerides and cholesterol of growing rabbits at the end of the experiment as affected by enzyme addition to their diets are presented in Table 4 .

The data revealed that, adding enzyme to rabbit diets did not significantly affect on the values of total protein, albumin, globulin, glucose, triglycerides and cholesterol. A slightly numerically im- 


\begin{tabular}{|c|c|c|c|c|c|c|}
\hline \multirow{2}{*}{ Treatments } & \multicolumn{6}{|c|}{ Items } \\
\hline & Total protein & Albumin & Globulin & Glucose & Triglyceri & Cholesterol \\
\hline \multicolumn{7}{|c|}{ Effect of sugar beet pulp levels SBP } \\
\hline Con0\%SBP & 5.30 & 1.71 & 3.57 & 157.54 & $114.01^{\mathrm{b}}$ & 99.01 \\
\hline $50 \%$ SBP & 5.46 & 1.78 & 3.67 & 165.57 & $107.95^{\mathrm{b}}$ & 99.01 \\
\hline $100 \%$ SBP & 5.60 & 1.87 & 3.72 & 163.13 & $150.76^{\mathrm{a}}$ & 99.63 \\
\hline SE & 0.29 & 0.07 & 0.23 & 13.55 & 10.06 & 0.12 \\
\hline Sig. & NS & NS & NS & NS & $*$ & NS \\
\hline \multicolumn{7}{|c|}{ Effect of enzyme addition (E) } \\
\hline Without E) & 5.23 & 1.80 & 3.43 & 156.53 & 118.52 & 99.12 \\
\hline With (E) & 5.68 & 1.79 & 3.88 & 167.63 & 129.97 & 99.4 \\
\hline$\pm \mathrm{SE}$ & 0.24 & 0.24 & 1.91 & 11.06 & 8.22 & 0.10 \\
\hline Sig. & NS & NS & NS & NS & NS & NS \\
\hline \multicolumn{7}{|c|}{ Interaction Without Enzyme } \\
\hline Con $0 \%$ & 5.10 & 1.78 & 3.31 & 162.04 & 124.76 & 98.92 \\
\hline $50 \%$ & 5.51 & 1.80 & 3.70 & 158.64 & 84.02 & 99.24 \\
\hline $100 \%$ & 5.08 & 1.80 & 3.27 & 148.90 & 146.78 & 99.48 \\
\hline \multicolumn{7}{|c|}{ Interaction with Enzyme } \\
\hline Con $0 \%$ & 5.50 & 1.64 & 3.84 & 153.04 & 103.24 & 99.10 \\
\hline $50 \%$ & 5.41 & 1.77 & 3.64 & 172.50 & 131.89 & 99.54 \\
\hline $100 \%$ & 6.13 & 1.95 & 4.17 & 177.37 & 154.80 & 99.79 \\
\hline$\pm \mathrm{SE}$ & 0.42 & 0.11 & 0.33 & 19.16 & 14.23 & 0.18 \\
\hline Sig. & NS & NS & NS & $*$ & $*$ & NS \\
\hline
\end{tabular}

Table 4: Effect of using dietary sugar beet pulp with or without enzyme addition on some metabolites responses of growing rabbits.

Values within column with no common superscripts are significantly different $(\mathrm{p}<0.05)$.

$\pm \mathrm{SE}=$ Stander error of means E=Enzyme

NS= Not significant

provement in the values of glucose and triglycerides was detected as a result of adding enzymes to rabbit diets compared with the control diet. These results are agree with the finding of Abaza and Omara [15]. They revealed that diets provided with enzymes had no significant effect on total protein, albumin, globulin and uric acid compared with diets without enzymes. Also, Zaza [5] reported that no significant differences were found among the rabbits fed biological treated SBP and control in total protein, albumin, globulin and A/G ratio. Moreover, Veselin., et al. [25] found no significant changes in the levels of the albumin and globulin in the blood of rabbits supplemented with Protozin multi-enzymes $(19 \mathrm{mg} / \mathrm{kg}$ diet) in the concentrate mixture.

The slightly improvement in glucose and triglycerides as a result of adding enzymes to rabbit diets may be due to that these enzymes can partially hydrolyze the non starch polysaccharides (NSP),reduce the viscosity of gut contents, and result in improvements in nutrient absorption. Several studies have been attempted for incorporating exogenous enzymes into rabbit diets to improve nutrients availability [26]. A significant increase in blood glucose levels, total lipids and total protein were observed in growing rabbits supplemented with kemzyme for 8 weeks [27]. These finding corroborated earlier observations of [28]. They found that kemzyme supplementation to the ration of growing turkey resulted in a significant increased level of blood glucose, total proteins and lipids. They attributed such finding to the improved digestibility and absorbability of different dietary elements, including carbohydrates, fat and proteins that was induced by the addition of exogenous enzymes. Such enrichment of bird's metabolic pools actively affects the blood levels of basic nutrients.

\section{Effect of interaction between diets and enzyme (E)}

Average values of some blood metabolic responses such as total protein, albumin, globulin, glucose, triglycerides and cholesterol of growing rabbits at the end of the experiment as affected by interaction between SBP level diets and enzyme addition in their diet are presented in Table 4.

The data revealed that, there are significant difference $(\mathrm{P}<0.05)$ in the values of glucose and triglycerides as a result of interaction 
between SBP levels diets and enzyme addition in rabbits diet. Rabbits fed dietary contain $100 \%$ SBP and incorporated with enzyme recorded the greatest value of glucose and triglycerides followed by others fed dietary contain 50\% SBP and incorporated with enzyme compared with all dietary treatment (SBPxenzyme). Using either SBP or adding enzyme to rabbit diets did not significantly affect on the values of total protein, albumin, globulin, and cholesterol. A slightly numerically improvement in the values of total protein, albumin and globulin were detected as a result of feeding rabbits on diet contain $100 \%$ SBP and incorporated with enzyme compared with all dietary (SBP×enzyme).

The previous results of plasma total protein, albumin and globulin are agree with the finding reported by El-Badawi., et al. [6], fed growing rabbits on either untreated sugar beet pulp (USBP) or fungal treated sugar beet pulp (TSBP) with Trichoderma reesei at levels of 25 and $50 \%$. They found that level of blood constituents included; total protein, and albumin not affect by treatment. Also, Yassein., et al. [29] showed that turkey plasma total protein, albumin and globulin concentration were not differ significantly as birds fed barley based-diets supplemented with or without enzymes (optizyme-p5) 1kg/ton. While, Abaza and Omara [15] revealed that the interaction between corn cobs levels and enzymes supplementation had a significant effect on total protein, globulin and uric acid. However, the differences between rabbits fed all levels of corn cobs with or without enzymes and the control diet in albumin were not significant.

\section{Liver function}

The effects of sugar beet pulp levels (diets), enzyme (E) addition, and the interaction between SBP diets and enzyme (E) addition on Aspartate amino tranaferase (AST,U/L), Alanine amino transferase (ALT,U/L) and (AST))/(ALT) ratio of the experiment are presented in Table 5.

\section{Effect of sugar beet pulp levels (diets)}

Average values of on AST, ALT and AST/ALT ratio of growing rabbits as affected by using different levels of SBP in their diet at the end of the experiment are presented Table 5.

The data revealed that, using SBP at all levels in rabbit diets had no significantly effect on the values of AST, ALT and AST/ALT ratio. Nevertheless, a slightly insignificantly improvement in ALT values was recorded for rabbit fed SBP diets up to 100\% compared with other SBP levels. Moreover, the values of AST and AST/ALT ratio were higher numerically for rabbits fed control diet followed with others fed dietary 50\% SBP. control treatments, but the differences were not significant. Ghally and Abd El- Latif [30] observed that, the lowest $(\mathrm{P}<0.05)$ values of ALT were observed when birds fed diets contain $1 \%$ yeast culture, and at the same time plasma AST increased $(\mathrm{P}<0.05)$ by adding yeast culture to the control diet up to 2\%.The positive effect on AIT and AST may be due to that the number of anaerobic and cellulytic bacteria were increased when the experimental diet was supplemented with yeast, which enhanced

\begin{tabular}{|l|c|c|c|}
\hline \multirow{2}{*}{ Treatments } & $\begin{array}{c}|c| \\
\text { Aspartate } \\
\text { aminotransfer- } \\
\text { ase (AST,U/L) }\end{array}$ & $\begin{array}{c}\text { Alanine } \\
\text { aminotrans- } \\
\text { feras (ALT,U/L) }\end{array}$ & $\begin{array}{c}\text { (AST,U/L) } \\
\text { (ALT,U/L) } \\
\text { Ratio }\end{array}$ \\
\hline \multicolumn{4}{|c|}{ Effect of sugar beet pulp levels } \\
\hline Con 0\%SBP & 23.55 & 15.12 & 1.55 \\
\hline $50 \%$ SBP & 22.68 & 14.96 & 1.51 \\
\hline $100 \%$ SBP & 20.58 & 15.30 & 1.34 \\
\hline \pm SE & 0.85 & 0.11 & 0.05 \\
\hline Sig. & NS & NS & NS \\
\hline \multicolumn{4}{|c|}{ Effect of enzyme (E) addition } \\
\hline Without E) & 21.67 & & 1.43 \\
\hline With (E) & 22.87 & & 1.51 \\
\hline \pm SE & 0.69 & & 0.04 \\
\hline Sig. & $*$ & & $*$ \\
\hline \multicolumn{4}{|c|}{ Interaction Without enzyme } \\
\hline Con 0\% & 23.73 & & 1.58 \\
\hline $50 \%$ & 22.80 & & 1.50 \\
\hline $100 \%$ & 18.48 & & 1.21 \\
\hline \multicolumn{4}{|c|}{ Interaction With enzyme } \\
\hline Con 0\% & 23.80 & & 0.08 \\
\hline $50 \%$ & 22.56 & & NS \\
\hline $100 \%$ & 22.68 & & 1.53 \\
\hline \pm SE & 1.20 & & \\
\hline Sig. & NS & & \\
\hline & & \\
\hline
\end{tabular}

Table 5: Effect of using dietary sugar beet pulp with or without enzyme addition on liver function responses of growing rabbits.

Values within column with no common superscripts are significantly different $(\mathrm{p}<0.05)$.

$\pm \mathrm{SE}=$ Stander error of means $\mathrm{E}=$ Enzyme

NS= Not significant

lactate utilization and moderates $\mathrm{pH}$ of themedia, Therefore, yeast improves the nutrients digestibility and growth performance of birds ( growing Japanese quail).

\section{Effect of enzyme addition}

Average values of on AST, ALT and AST/ALT ratio of growing rabbits at the end of the experiment as affected by enzyme addition to their diets are presented Table 5.

The data revealed that, there are significant difference $(\mathrm{P}<0.05)$ in the values of AST and AST/ALT ratio between dietary enzyme and control diet. However, this difference was not significant for the values of ALT enzyme among treatments. It could be noticed that rabbit fed dietary enzyme recorded the greatest $(\mathrm{P}<0.05)$ enhancement in the values of AST and AST/ALT ratio compared with the control diet.

These results were in a harmony with the data of Abaza and Omara [15]. They revealed that diets provided with enzymes sig- 
nificantly decreased AST value for rabbits compared with those fed diets without enzymes, whereas ALT values were not significantly affected by enzymes. Supplementation of enzymes improved the liver functions AST and ALT values. Also, El-Gendi., et al. [31] found that chicks fed Kenzyme had the highest average of ALT (7.51 u/l). On the other hand, Salem., et al. [32] who reported that Avizyme supplementation had no significant effect on plasma AST concentration. Kemzyme did not significantly affect plasma AST concentration. Also when Avizyme and Kemzyme were added together, plasma AST concentration was not significantly affected.

\section{Effect of interaction between diets and enzyme (E)}

Average values of AST, ALT and AST/ALT ratio of growing rabbits at the end of the experiment as affected by interaction between SBP level diets and enzyme addition in their diet are presented in Table 5.

The data revealed that, there are no significant difference ( $P>0.05$ ) in the values of AST, U/L, ALT, U/L and AST/ALT, U/L ratio as a result of interaction between SBP levels diets and enzyme addition in rabbits diet. Rabbits fed dietary contain 100\% SBP and incorporated with enzyme recorded slightly numerically value of ALT followed by others fed dietary contain $100 \%$ SBP without enzyme compared compared with all dietary interaction treatments. While, rabbits fed control diet either with or without enzyme addition recorded the best numerically values of ALT, U/L and AST/ALT, $\mathrm{U} / \mathrm{L}$ ratio compared with all dietary interactions (SBP $\times$ enzyme). The previous data are harmony with finding of, El-Badawi., et al [6]. However, values ALT were higher for rabbits fed fungal treated sugar beet pulp (TSBP) than the other groups. Also, Zaza [5] reported that no significant differences were found among the rabbits fed biological treated SBP and control in AST and ALT. While, Abaza and Omara [15] revealed that the interaction between corn cobs levels and enzymes supplementation had a significant effect on AST and ALT. Rabbits fed diets containing different levels of corn cobs and provided with enzymes recorded the lowest significant $(\mathrm{P}<0.05)$ values of AST and ALT compared with those fed corn cobs without enzymes supplementation. Also, better values of both AST and ALT were recorded for rabbits fed the control diet with enzymes compared with those fed diets containing corn cobs without or with enzymes.

\section{Conclusion}

From the present study It could be concluded that, using SBP in rabbit diets with exogenous enzymes addition had no adverse affects on liver function of other metabolic items studied. Also, adding enzymes to rabbit diets may enhance liver enzymes of the growing rabbits.

\section{Bibliography}

1. Gidenne T and R Bellier. "Use of rapidly fermented fiber in replacement to available carbohydrates: Effect on digestion, rate of passage and caecal fermention pattern during the growth of the rabbit". Livestock Production Science 63 (2000): 141-152.

2. Western Sugar Molasses beet pulp pellets (2016).

3. EL-Badawi AY and RI EL-Kady. "Effect of partial replacement of concentrates with sugar beet pulp on performance, carcass characteristics and energy utilization of growing sheep". International Journal of Agriculture and Biology 8.3 (2006).

4. Volek Z., et al. "Comparison of diets for growing rabbits containing potato pulp, sugar beet pulp and wheat bran: effect on performance and digestion parameters". Archiv fur Geflugelkunde 68.6 (2004): 259-264.

5. Zaza GHM. "Effect of incorporation of biologically treated sugar beet pulp as non-conventional feed stuffs in the diets of growing rabbits". The 4th Inter. Con. On Rabbits Prod. In hot climates. SharmEl-Sheikh, Egypt. (2005).

6. El-Badawi AY., et al. "Growth Performance of new-zealand white rabbits fed diets containing different levels of untreated or fungal treated sugar beet pulp". 58th EAAP Meeting, Dublin (2007).

7. Salah El-Din S Aboul-Ela and FM Reda. "Effect of Egyptian clover hay substitution with sugar beet pulp on growing rabbits performance". Zagazig journal of agricultural research 43.6 (2016).

8. Acamovic T. "Commercial application of enzyme technology for poultry production". World's Poultry Science Journal 57.3 (2001): 225-242.

9. Slominski BA. "Recent Advances in research on enzymes for poultry diets". Poultry Science 90.9 (2011): 2013-2023.

10. El-Badawi AY., et al. "Effect of replacing corn with sugar beet pulp on ruminal degradation kinetics and utilization efficiency of rations by growing sheep". Egyptian Journal of Nutrition and Feeds 6 (2003): 1349-1363.

11. Cobos Angel., et al. "Sugar beet pulp as an alternative ingredient of barley in rabbit diets and its effect on rabbit meat". Meat Science 39.1 (1995): 113-121.

12. Tag EL-Din TH. "Protective performance of meet rabbit as affected by partial replacement of clover hay by okra and sugar beet pulp processing by -products". The Journal of Agricultural Science, Mansoura University 21.12 (1996): 4339-4350. 
13. Abedo AA AbdEl-Maged. "A study on the use of sugar beet pulp in the feed mixtures for ruminants". Ph. P. Thesis. Fac. of Agric. Ain- Shams Univ. (2006).

14. Makled MN., et al. "Impact of different levels of dietary multienzymes supplement on California rabbit performance. $3^{\text {rd" }}$. International Poultry Conference, Hunghada, Egypt (2005).

15. Abaza IM and ME Omara. "Effect of dietary corn cobs and enzymes supplementation on growing rabbits performance". Journal of Product Development 16.3 (2011): 507-527.

16. Eiben CS., et al. "Dose-dependent effect of cellulose supplementation on performance of early-weaned rabbit". In Proc. 8th World Rabbit Congress, Puebla, México (2004) 799-804.

17. Fasiullah MSZH., et al. "Effect of dietary enzyme supplementation on nutrient utilizationand growth performance of rabbit". International Journal of Biological Research 1.3 (2010): 17-21.

18. NRC National Research Council.Nutrient Requirements of Rabbits.9th Edition, National Academy Press, Washington, D.C. (1994).

19. Tietz NW. "Fundamental of clinical chemistry: 2nd ed". (1994): 692.

20. Tietz NW and WB Saunders. "Clinical guide to laboratory tests: 2nd ed". Philadelphia. (1990): 26-29.

21. Young DS. "Effect of drugs on clinical laboratory tests". 3rd Ed. AACC Press, Washington, USA. (1990).

22. SAS, Statistical Analysis system. SAS users Guide statistics. SAS institute inc; Cary, NC. (1998).

23. Duncan DB. "Multiple range and multiple F-test". Biometrics 11.1 (1955): 1-42.

24. Abd EL-Latif SA., et al. "Effect of replacing hay by sugar beet pulp in growing rabbit diets on some productive, metabolic responses and economical efficiency". Egyptian Journal of Animal Production 47.1 (2012): 141-149.

25. Veselin R., et al. "Changes in Hematological parameters of rabbits given multi-enzyme Protozin in the diet". Trakia Journal of Sciences 1 (2003): 67-71.

26. Falcao-e-Cunha L., et al. "Alternatives to antibiotic growth promoters inrabbit feeding: a review". World Rabbit Science 15.3 (2007): 127-140.

27. Attia KA. "Effects of exogenous multi-enzymefeed additive (kemzyme) on the activities of certain digestive enzymes and intestinalmorphology ingrowing rabbits". Journal of Agricultural Science 4.3 (2012).
28. Saleh SY., et al. "Effect of multi-enzymes feed additive on performance and some metabolic parameters in turkeys". Kafr ElSheikh Veterinary Medical Journal 4.1 (2006): 1307-1319.

29. Yassein SA., et al. "Barley as replacement for yellow corn with or without enzyme or DL-methionine in practical diets of growing turkeys". Egyptian Poultry Science Journal 24.4 (2004): 929-944.

30. Ghally KA and SA Abd El-Latif. "Effect of dietary yeast on some productive and physiological aspects of growing Japanese quails". African Crop Science conference 8 (2007): 2147-2151.

31. El-Gendi GM., et al. "Evaluating four feed additives for improving productive and metabolic performance of broiler chicks". Egyptian Poultry Science Journal 20 (2000): 103-122.

32. Salem AA., et al. "Productive and physiological performance of Golden Montazah male chickens as affected by feed restriction and Avizyme supplementation". Egyptian Poultry Science Journal 28 (2008): 1137-1164.

\section{Volume 3 Issue 8 August 2019}

(C) All rights are reserved by Aya SA Abd El-Latif., et al. 